\title{
Colchicine-derived compound CT20126 promotes skin allograft survival by regulating the balance of Th1 and Th2 cytokine production
}

\author{
Seon-Jin Lee ${ }^{1,2}$, Seung Namkoong ${ }^{1,2}$, \\ Kwon-Soo $\mathrm{Ha}^{1,2}$, Woo-Dong $\mathrm{Nam}^{3}$, \\ Young-Guen Kwon ${ }^{4}$, Hansoo Lee ${ }^{1}$, \\ Eun-Young Yoon ${ }^{5}$, Dong-Jo Chang ${ }^{5}$, \\ Soon-OK Kim ${ }^{5}$ and Young-Myeong $\mathrm{Kim}^{1,2,6}$ \\ ${ }^{1}$ Vascular System Research Center \\ ${ }^{2}$ Department of Molecular and Cellular Biochemistry \\ ${ }^{3}$ Department of Orthopaedic Surgery \\ School of Medicine, Kangwon National University \\ Chuncheon 200-701, Korea \\ ${ }^{4}$ Department of Biochemistry \\ College of Medicine, Yonsei University \\ Seoul 120-749, Korea \\ ${ }^{5}$ Team of Biotech and Drug Development \\ Chem-Tech Research Incorporation, Suwon University \\ Hwaseong 445-743, Korea \\ ${ }^{6}$ Corresponding author: Tel, 82-33-250-8831; \\ Fax, 82-33-244-3286; E-mail, ymkim@kangwon.ac.kr
}

Accepted 27 February 2007

Abbreviations: CsA, cyclosporine A; NO, nitric oxide; NOx, nitric plus nitrate

\begin{abstract}
Colchicine has been shown to regulate the expression of inflammatory gene, but this compound possesses much weaker anti-inflammatory activity. In this study, we synthesized a new colchicine derivative CT20126 and examined its immunomodulatory property. CT20126 was found to have immunosuppressive effects by inhibiting lymphocyte proliferation without cytotoxicity and effectively inhibit the transcriptional expression of the inflam matory genes, iNOS, TNF- $\alpha$, and IL- $1 \beta$, in macrophages stimulated by LPS. This effect was nearly comparable to that of cyclosporine A. This com pound also significantly suppressed the production of nitric oxide and Th1-related pro-inflammatory cytokines, IL-1 $\beta$, TNF- $\alpha$, and IL-2, with minimal suppression of Th2-related anti-inflammatory cyto kines IL-4 and IL-10 in the sponge matrix allograft model. Moreover, administration of СT20126 pro-
\end{abstract}

longed the survival of allograft skins from BALB/c mice $\left(\mathrm{H}-2^{\mathrm{d}}\right)$ to the dorsum of $\mathrm{C} 57 \mathrm{BL} / 6\left(\mathrm{H}-2^{\mathrm{b}}\right)$ mice. The in vivo immune suppressive effects of CT20126 were similar to that of cyclosporine A. These results indicate that this compound may have potential therapeutic value for transplantation rejection and other inflammatory diseases.

Keywords: colchicine; cytokines; inflammation; immunosuppressive agents; T-lymphocytes, helper-inducer; transplantation, homologous

\section{Introduction}

The recent development of organ transplantation for clinical purposes is enabled by the use of immunosuppressive drugs which inhibit or modulate immune response to graft antigens. The most extensively used immunosuppressive drugs are cyclosporine A (CsA), tacrolimus, and sirolimus (Smith et al., 2003). All these drugs affect not only the cells of the immune system, but have some adverse functions on other cells or tissues (Saeed et al., 2006). These immunosuppressants have been shown to inhibit the production of nitric oxide (NO), IL-1 $\beta$, and TNF- $\alpha$ as cytotoxic molecules participating in graft rejection by graft-infiltrating macrophages (Krulova et al., 2002; Matsue et al., 2002). The level of NO produced after transplantation correlates with the kinetics of rejection reaction and with the fate of the graft using an experimental mouse model (Krulova et al., 2002). The suppression of NO production from infiltrating macrophages by the specific inhibitor of iNOS resulted in a significant prolongation of survival of skin and heart allografts (Worrall et al., 1995; Krulova et al., 2002).

The polarization of immune response towards either Th1 or Th2 has also been described in transplantation models. Acute allograft rejection is usually associated with the production of Th1-like or -related cytokines (IL-1 $\beta$, TNF- $\alpha$, IL-2, and IFN- $\gamma$ ), although Th2 cytokines (IL-3, IL-4, and IL-10) can also be elevated in rejecting grafts. In contrast, allograft tolerance is characterized by decreased expression of Th1-like or -related cytokines and/or elevated Th2 cytokines (Wu et al., 1992; Strom et al., 1996). Of Th2 cytokines, IL-4 and IL-10 showed synergistic 
and antagonistic immunoregulatory capacities, such as elevation of Th2 cytokine gene expression and suppression of NO production and macrophage cytotoxic activity (Oswald et al., 1992; SchmidtWeber et al., 1999), leading to prolongation of allograft survival (Furukawa et al., 2005). In addition, treatment with immunosuppressants such as tacrolimus and sirolimus decreased capacity to produce Th1-mediated pro-inflammatory cytokines and prolonged allograft survival (Matsue et al., 2002). It indicates that the expression levels of Th1 and Th2 cytokines are thought to play an important role in the regulation of tolerance in organ transplantation.

The microtubule-depolymerizing agent colchicine has been shown to regulate the expression of inflammatory gene such as iNOS (Gahm et al., 2005), but this compound possesses much weaker antiinflammatory activity than that of CsA and tacrolimus. In this study, we synthesize a new colchicine derivative CT20126 with potential immunomodulatory properties. This new drug effectively suppressed inflammatory mediators including NO, IL-1 $\beta$, TNF- $\alpha$, and IL-2, but minimally affected IL-4 and IL-10 in cultured macrophages and the sponge graft system. Furthermore, this compound delayed skin allograft rejection. These results indicate that CT20126 may be a useful drug for the treatment of graft rejection and other human inflammatory diseases.

\section{Materials and Methods}

\section{Cell culture}

RAW264.7 cells (murine macrophage cell line) were obtained from American Type Culture Collection (Manassas, VA). Peritoneal macrophages were collected from the peritoneal cavity of 6- to 8-week- old female BALB/c mice (Charles River Breeding Laboratory) given an i.p. injection of $1.5 \mathrm{ml}$ of thioglycollate broth (4\%) 7 days before harvest. Cells were cultured in DMEM (Life Technology Inc., Rockville, MD) containing $2 \mathrm{mM}$ L-glutamine, $100 \mathrm{U} / \mathrm{ml}$ penicillin, $100 \mu \mathrm{g} / \mathrm{ml}$ streptomycin and 10\% FBS in a humidified incubator with $5 \% \mathrm{CO}_{2} / 95 \%$ air at $37^{\circ} \mathrm{C}$. Cells were treated with colchicine-based derivatives (referred as CT compounds) in the presence of LPS $(2 \mu \mathrm{g} / \mathrm{ml})$.

\section{Animals}

Female C57BL/6 $\left(\mathrm{H}-2^{\mathrm{b}}\right)$ and BALB/C $\left(\mathrm{H}-2^{\mathrm{d}}\right)$ mice used in this study were obtained from Orients (Seongnam, Korea) and maintained at the specific pathogen-free housing facility at the School of Medicine, Kangwon National University (Chuncheon, Korea). All procedures performed on these animals were in accordance with the guidelines of the University Animal Care and Use Committee. All mice were used between 6 and 8 weeks of age.

\section{Assays of mixed lymphocyte response (MLR) and cytotoxicity}

Freshly harvested splenocytes from C57BL/6 and $B A L B / c$ mice were used as stimulator and responder cells, respectively. Stimulator cells were resuspended and treated with $50 \mu \mathrm{g} / \mathrm{ml}$ mitomycin $\mathrm{C}$ (as a final concentration, Sigma) at $37^{\circ} \mathrm{C}$ for $30 \mathrm{~min}$ to inhibit their proliferation. Cells were quickly washed twice with RPMI 1640, combined with responder cells in 96 -well plates at a $4: 1$ ratio $\left(5 \times 10^{5}\right.$ cells: $1.25 \times 10^{5}$ cells; stimulator:responder) with various concentrations of CT compounds and cultured for 3 days. The proliferation of lymphocytes was measured by cell proliferation assay kit-8. For cytotoxicity assay, splenocytes from BALB/c mice were cultured in 96-well plates with various concentrations of CT compound in the presence of $5 \mu \mathrm{g} / \mathrm{ml}$ pokeweed mitogen (Sigma) for 3 days. Cell proliferation was measured by cell proliferation assay kit-8.

\section{Measurements of NO and cytokines}

The levels of nitrite in the culture media and nitrite plus nitrate (NOx) in sponge exudate fluid, as stable products of NO, were measured by Griess reagents (Lee et al., 2003) and nitrate reductase-based colorimetric assay kit (Alexis San Diego), respectively. The levels of TNF- $\alpha, \mathrm{IL}-1 \beta, \mathrm{IL}-2, \mathrm{IL}-4$, and IL-10 were determined using ELISA kits purchased from R\&D Systems (Minneapolis).

\section{Western blot and real-time PCR analyses}

Cells were harvested, washed twice with ice-cold

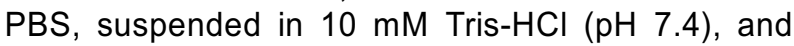
lysed by three cycles of freezing and thawing. Cell extracts were obtained by centrifugation at $12,000 \mathrm{~g}$ at $4^{\circ} \mathrm{C}$ for $20 \mathrm{~min}$. Intracellular levels of inflammationassociated proteins were determined by Western blot analysis as previously described (Lee et al., 2003). For real-time PCR analysis, total RNAs from macrophages and their cDNA were prepared by previous methods (Lee et al., 2003). Quantitative PCR was performed by applying the real-time Taqman PCR technology with the use of an $A B I$ PRISM 7000 sequence detection system (Applied Biosystems). The murine iNOS, TNF- $\alpha, \mathrm{IL}-1 \beta$ and GAPDH primers were purchased from Applied Biosystems (Foster City, CA). cDNA samples were mixed with primers/probe cocktails of $12.5 \mu \mathrm{l}$ and TaqMan Universal PCR Master Mix (Applied Biosystems) in a total volume of $25 \mu$ l containing $10 \mu \mathrm{l}$ 
of cDNA. This corresponded to $1.25 \mathrm{U}$ of AmpliTaq Gold DNA polymerase, $0.5 \mathrm{U}$ of AmpEase uracil $N$-glycosylase (UNG), $200 \mu \mathrm{M}$ each of dATP, dCTP and dGTP, $400 \mu \mathrm{M}$ of dUTP, 10× TaqMan Buffer A, and $25 \mathrm{mM}$ of $\mathrm{MgCl}_{2}$. The AmpErase UNG activity, in combination with dUTP, was used to prevent contamination by the carry-over of PCR products. Buffer A contains passive reference I for signal normalization in all TaqMan reactions. The samples were amplified using the following thermal cycling conditions: the initial step of $50^{\circ} \mathrm{C}$ for 2 min and $95^{\circ} \mathrm{C}$ for $10 \mathrm{~min}$, followed by 40 cycles of amplification at $95^{\circ} \mathrm{C}$ for $15 \mathrm{~s}$, and then $60^{\circ} \mathrm{C}$ for $1 \mathrm{~min}$ to allow for denaturing and annealing-extension. The cycle at which this baseline level is exceeded is defined as threshold cycle. Quantitative real-time PCR was performed for iNOS, TNF- $\alpha$, and IL-1 $\beta$ and normalized to the copies of GAPDH mRNA from the same sample. All PCR assays were performed in duplicate and results are represented by the mean values. All calculations followed procedures outlined in $A B I$ PRISM 7000 sequence detective system bulletin.

\section{Sponge matrix graft model}

The sponge matrix allograft model has been used frequently to investigate the components of the allograft response in vivo (Hoffman et al., 1988). Sterile polyurethane sponges measuring $10 \times 10 \times$ $5 \mathrm{~mm}$ (32 $\pm 2 \mathrm{mg}$ ) were soaked in minimal essential media supplemented with $100 \mathrm{U} / \mathrm{ml}$ of penicillin and streptomycin. A 20-mm skin incision was made on the dorsolateral thorax of recipient $\mathrm{C} 57 \mathrm{BL} / 6$ mice, and then implanted subcutaneously over the shoulders of anesthetized mice under aseptic conditions. Before skin closure with wound clips, each sponge was injected with $0.2 \mathrm{ml}$ of syngeneic C57BL/6 and allogeneic BALB/c splenocyte suspension $\left(1 \times 10^{7}\right.$ cells), while a control group was injected with splenocyte-free DMEM supplemented with antibiotics as above. Mice were i.p. injected with CT20126 (1 $\mathrm{mg} / \mathrm{kg}$ ) or CsA (1 mg/kg) for 8 days. The sponges were excised surgically and gently squeezed into separate sterile tubes to collect the sponge exudate fluid. The sponge exudates were centrifugated at $1,500 \mathrm{~g}$ for $15 \mathrm{~min}$. The cell free supernatant was stored at $-70^{\circ} \mathrm{C}$.

\section{Skin graft experiment}

Full thickness skins from BALB/c mice were grafted and transplanted on the back of C57BL/6 mice. The donor BALB/c mice were anesthetized by an i.p. injection of $4 \%$ avertin, hairs on the back were removed, and the full-thickness dorsal skins were peeled off. The skins were washed with $70 \%$ ethanol and minimal essential medium, and cut into $1 \times 1$ $\mathrm{cm}$ squares. The recipient $B A L B / c$ mice were anesthetized, and the skins were peeled off at the pannicular level to prepare the graft bed by $1.2 \times$ $1.2 \mathrm{~cm}$. The donor skin was placed on the recipient bed and then covered with a vaseline gauze and tied with a band-aid for mechanical fixation. Mice were i.p. administrated with or without daily doses of 1 $\mathrm{mg} / \mathrm{kg}$ of CT20126, $1 \mathrm{mg} / \mathrm{kg}$ of CsA or $1 \mathrm{mg} / \mathrm{kg}$ of colchicine. The grafts were considered to be rejected when at least $70 \%$ of the graft tissue had disappeared or had shrunken. Graft survival on a specific day was expressed as the proportion of the non-rejected grafts out of the total number of grafts.

\section{Statistical analysis}

Data are presented as the mean \pm SD of at least three separate experiments. Comparisons between two groups were analyzed using Student's $t$-test. $P$ values less than 0.05 were considered to be statistically significant.

\section{Results}

\section{Immune regulatory activities of colchicine and its derivatives}

To evaluate the biological activities of $100 \mathrm{CT}$ compounds synthesized from commercially available colchicine, the effects of these compounds on lymphocyte proliferation and cytotoxicity of spleen cells were measured using MLR and apoptosis assay and compared to the effects of colchicine and CsA. Of these compounds, 6 compounds effectively inhibited MLR in a dose-dependent manner and their effects were similar to that of CsA and were much higher than that of colchicine (Figure 1A), without significant cytotoxicity of splenocytes, as determined by crystal violet staining (data not shown). These results suggest that these compounds show inhibitory activity against $\mathrm{T}$ lymphocytes by decreasing proliferation without cytotoxicity. NO production by macrophages infiltrated into inflammatory tissue has been proposed as an important immune mechanism of allograft rejection as well as the pathogenesis of inflammatory disease (Holan et al., 2001). To examine the immunosuppressive effects of these new compounds, we measured their inhibitory activities against NO production from macrophages. Murine macrophage RAW264.7 cells treated with 6 CT compounds $(10 \mu \mathrm{M})$ in the presence of LPS, CT20006, CT20007, CT20032, and CT20087 moderately suppressed NO production to about $30-40 \%$ compared with NO level of LPS treatment alone (Figure 1B). The effects of CT20015 and CT20126 on NO production were much higher than that of colchicine and 

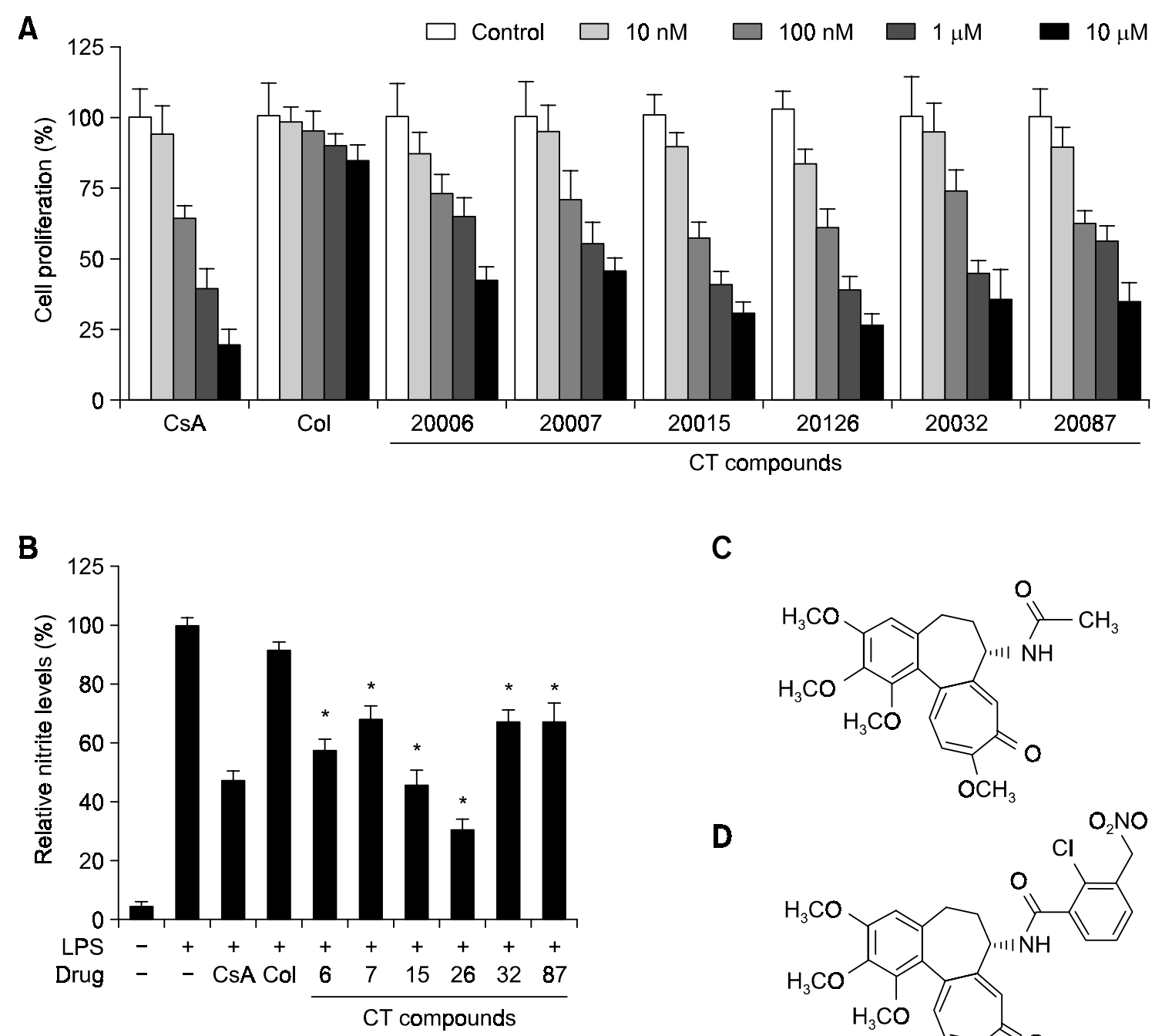<smiles>COc1cc2c(c(OC)c1OC)-c1cc(OC)c(OC)c(OC)c1-c1ccc(OC)c(=O)cc1[C@@H](NC(C)=O)CC2</smiles>

Figure 1. Effects of CT compounds on mixed lymphocytes reaction and NO production. (A) Lymphocytes $\left(5 \times 10^{5}\right)$ from C57BL/6 mice were incubated with lymphocytes $\left(1.25 \times 10^{5}\right)$ from BALB/c mice, which had been treated with mitomycin $\mathrm{C}(50 \mu \mathrm{g} / \mathrm{ml})$ for 30 $\mathrm{min}$ in the presence or absence of various concentrations of CT compounds, colchicine (Col) or cyclosporine $\mathrm{A}(\mathrm{CsA})$ at $37^{\circ} \mathrm{C}$ in $5 \%$ $\mathrm{CO}_{2}$ for 3 days. The proliferation of lymphocytes was measured by cell proliferation assay kit-8. (B) RAW264.7 cells were treated with $10 \mu \mathrm{M}$ of CT compounds, colchicine (Col) or cyclosporine $\mathrm{A}(\mathrm{CsA})$ in the presence of $1 \mu \mathrm{g} / \mathrm{ml}$ LPS for $18 \mathrm{~h}$. Nitrite, as a stable oxidized product of NO, were determined by Griess reagents. The nitrite level in the culture media of LPS-stimulated macrophages was $26.4 \mu \mathrm{M}$, which is expressed as $100 \%$. All data are the mean $\pm \mathrm{SD}(n \geq 3)$. ${ }^{*} P<0.01$ versus LPS alone. Molecular structures of colchicine (C) and CT-20126 (D).

were comparable to that of CsA. However, the inhibitory effect of CT20126 was higher than that of CT20015 (70\% vs. 55\%). These results suggest that CT20126 has potential anti-inflammatory or immunosuppressive activity. Figure $1 \mathrm{C}$ and $1 \mathrm{D}$ show the molecular structures of colchicine and its derivative CT20126. On the basis of their chemical structures, the immune regulatory effect of CT20126 may be attributed to the substitution of a methyl group in colchicine to a benzyl chloride moiety.
CT20126 inhibits the expression of NO, TNF- $\alpha$, and IL-1 $\beta$ in RAW264.7 cells stimulated with LPS

It has been known that iNOS, TNF- $\alpha$, and IL-1 $\beta$ expression in immune-activated macrophages are potential markers of inflammation (Lee et al., 2003). Experiments were performed to determine whether CT20126 influences the accumulation of NO, TNF- $\alpha$, and IL-1 $\beta$ in the culture media of RAW264.7 cells exposed to LPS. Immune-activated RAW264.7 cells showed a significant production of nitrite (as a stable 

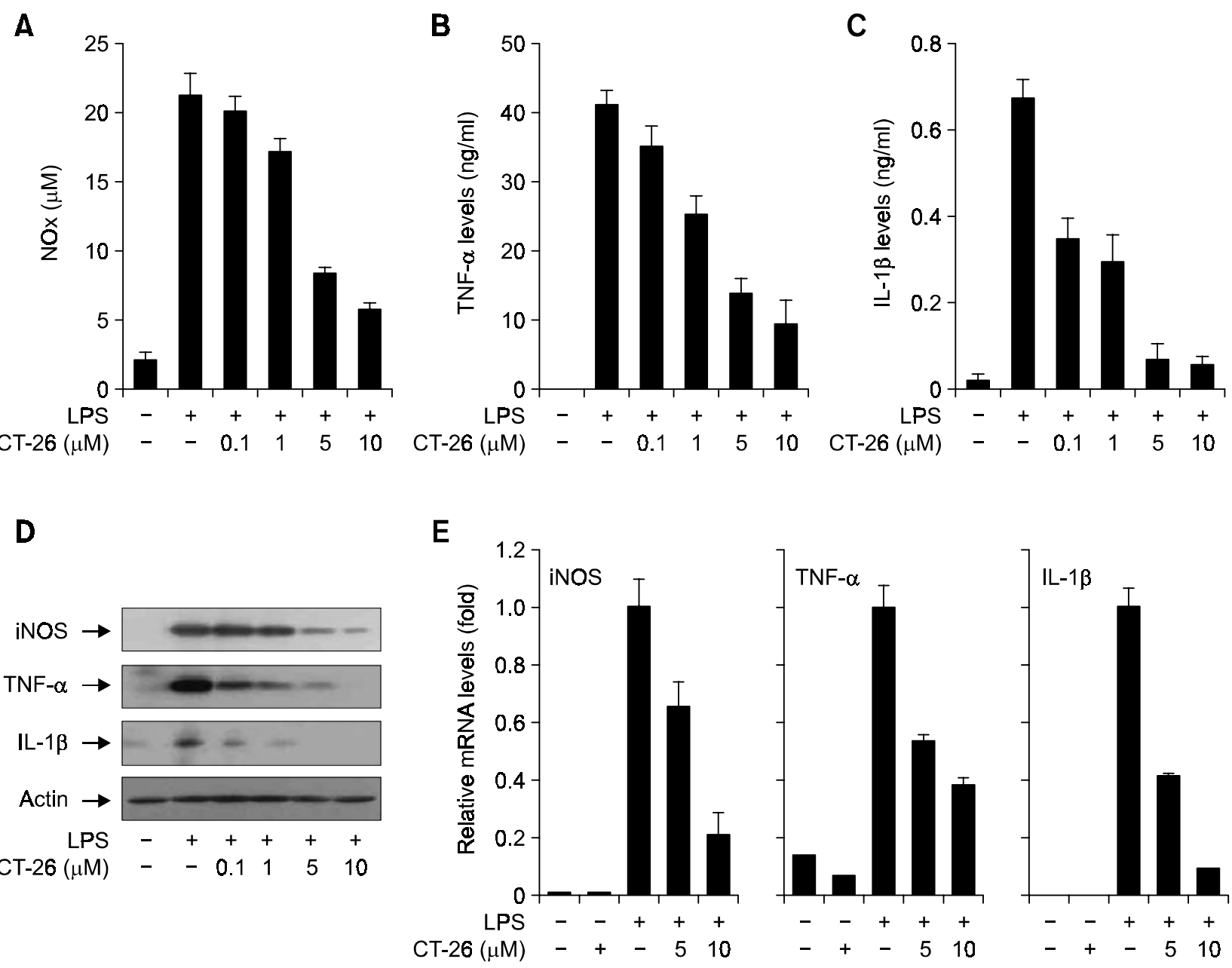

Figure 2. CT20126 inhibits the expression of iNOS, TNF- $\alpha$, and IL-1 $\beta$ in LPS-stimulated RAW264.7 cells. RAW264.7 cells were stimulated with LPS $(1 \mu \mathrm{g} / \mathrm{ml})$ in the presence or absence of different concentrations of CT20126 (CT-26). After $18 \mathrm{~h}$, nitrite (A), TNF- $\alpha$ (B), and IL-1 13 (C) levels were measured in the culture medium by Griess reagents and ELISA kits. Data shown are the mean \pm SD $(n \geq 3)$. (D) After stimulation with LPS for 18 $\mathrm{h}$, cells were harvested, washed twice with ice-cold PBS, and lysed by three cycles of freezing and thawing. Cytosolic extracts were prepared by centrifugation at $12,000 \times \mathrm{g}$ for $20 \mathrm{~min}$. Cytosolic proteins $(30 \mu \mathrm{g})$ were separated on SDS-PAGE and transferred onto nitrocellulose membrane. The protein levels of iNOS, TNF- $\alpha$, and IL-1 $\beta$ were measured by Western blot analyses using antibodies against mouse iNOS, TNF- $\alpha$, and IL-1 $\beta$. The blot was rehybridized with actin antibody to verify equal loading of protein in each lane. (E) The levels of iNOS, TNF- $\alpha$, and IL-1 3 mRNAs were determined in LPS-stimulated RAW264.7 cells for $6 \mathrm{~h}$ by real time-PCR analysis. The mRNA levels were calculated from the mRNA ratio of cytokine gene/GAPDH. Data shown are the mean $\pm \mathrm{SD}(n \geq 3)$.

oxidized product of NO), TNF- $\alpha$, and IL-1 $\beta$ in the culture medium, and these elevations were inhibited in a dose-dependent manner with an $\mathrm{IC}_{50}$ value of $\sim 4 \mu \mathrm{M}$ by CT20126 treatment (Figure 2A-C). We next examined whether CT20126 inhibits the intracellular protein levels of iNOS, pro-TNF- $\alpha$ and proIL-1 $\beta$. Western blot analyses showed that CT20126 treatment suppressed the intracellular protein levels of iNOS and the pro-forms of TNF- $\alpha$ and IL- $1 \beta$ in a dose-dependent manner and almost completely inhibited these protein levels at a concentration of 10 $\mu \mathrm{M}$ (Figure 2D). We further examined the effects of CT20126 on the mRNA levels of iNOS, TNF- $\alpha$, and
IL-1 $\beta$. Real time-PCR analyses showed that CT20126 inhibited LPS-mediated increases in these mRNA levels in a dose-dependent manner (Figure 2E). These results suggest that CT20126 inhibits NO, TNF- $\alpha$, and IL-1 $\beta$ production through the suppression of iNOS, TNF- $\alpha$, and IL- $1 \beta$ expression at the transcriptional step in LPS-stimulated RAW264.7 macrophages, respectively.

\section{Immunosuppressive effects of CT20126 in the sponge matrix graft model}

Sponge matrix allograft has been used as an in vivo 
A

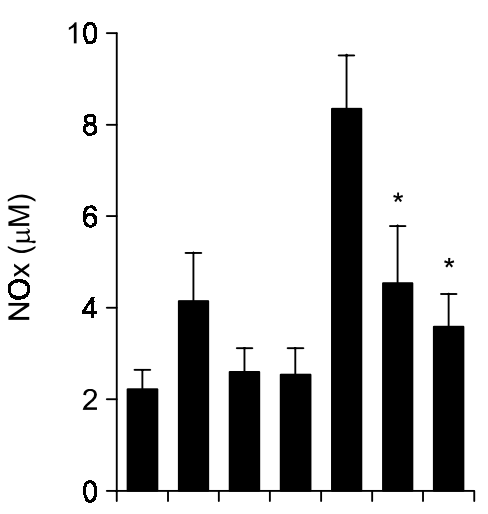

D

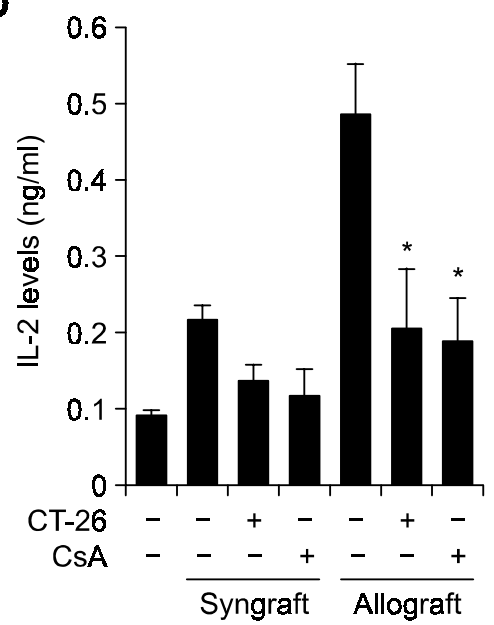

B

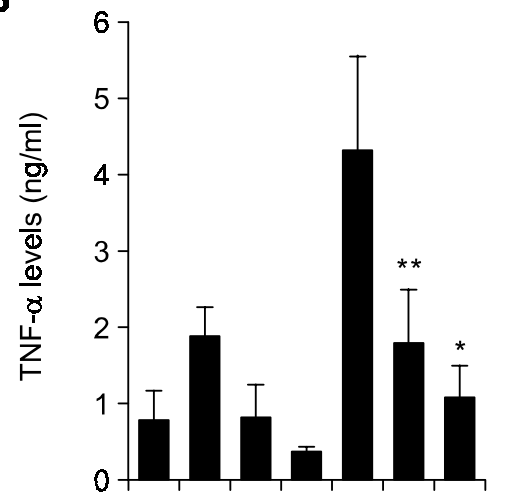

E

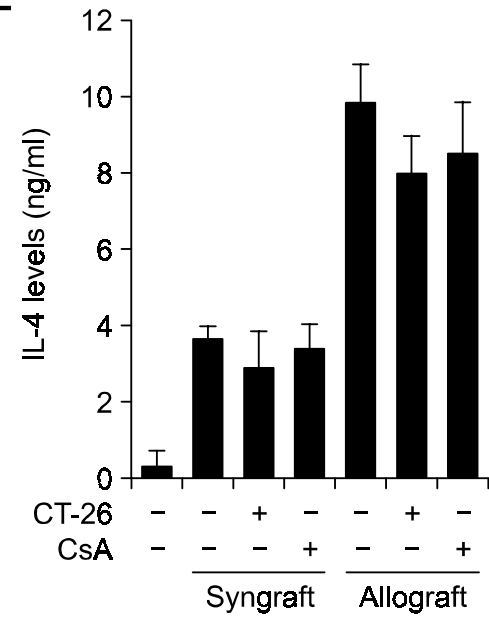

C

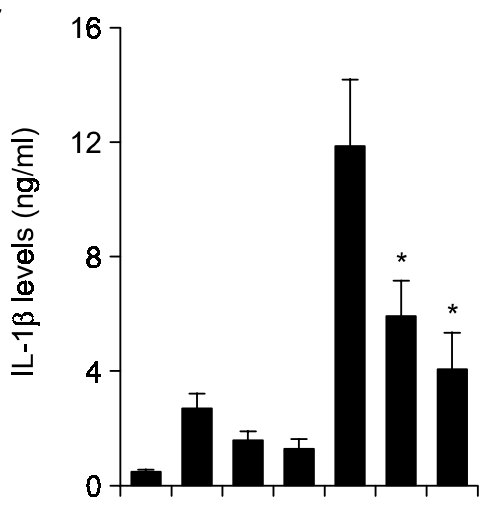

$\mathbf{F}$

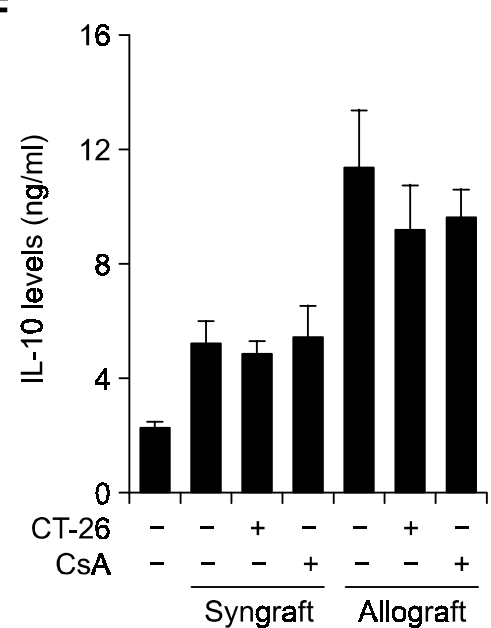

Figure 3. CT20126 inhibits the levels of nitric oxide metabolites and cytokines in the sponge matrix graft model. Sterile sponges were soaked in minimal essential media supplemented with $100 \mathrm{U} / \mathrm{ml}$ of penicillin and streptomycin and subcutaneously over the shoulders of anesthetized C57BL/6 mice under aseptic conditions. Each sponge was injected with $0.2 \mathrm{ml}$ of syngeneic $\mathrm{C} 57 \mathrm{BL} / 6$ and allogeneic BALB/c splenocyte suspension $\left(1 \times 10^{7}\right.$ cells), while a control group was injected with splenocyte-free medium. Mice were i.p. injected with CT20126 (CT-26, $1 \mathrm{mg} / \mathrm{kg} / \mathrm{day}$ ) or CsA (1 mg/kg/day) for 8 days. The sponges were excised surgically and squeezed gently into separate sterile tubes to collect the sponge exudate fluid. The sponge exudates were centrifugated at $1,500 \times g$ for $15 \mathrm{~min}$. The levels of nitric oxide metabolites and cytokines were determined in the sponge exudate fluid using nitrate reductase-based colorimetric assay kit and ELISA kits. Data shown are the mean $\pm \operatorname{SD}(n \geq 5)$. ${ }^{* *} P<0.05 ;{ }^{*} P<0.01$ versus non-treated allograft.

model system to study lymphocyte activity and graft-infiltrating cell-associated cytokine production (Ford et al., 1991). We examined the immunosuppressive effects of CT20126 on inflammatory mediator production in sponge matrix grafts, which were implanted into C57BL/6 mice and injected with either $\mathrm{C} 57 \mathrm{BL} / 6$ or $\mathrm{BALB} / \mathrm{c}$ splenocytes. Production of NO metabolites, TNF- $\alpha$, IL-1 $1 \beta$, IL-4, and IL-10 was slightly increased in exudates obtained from sponge matrix syngeneic grafts compared with the splenocyte-free control, and significantly elevated in allogeneic sponge fluids (Figure 3). Administration with CT20126 significantly inhibited the production of the pro-inflammatory mediators, nitrite plus nitrate (NOx),
TNF- $\alpha$, IL-1 $\beta$, and IL-2 (Figure 3A-D), but not significantly suppress Th2-meiated anti-inflammatory cytokines IL-4 and IL-10 in the allogeneic sponge exudates (Figure $3 \mathrm{E}$ and $3 \mathrm{~F}$ ). These inhibitory effects of CT20126 were comparable to the effect of CsA. These results indicate that CT20126 can offset the relative balance of Th1/Th2 cytokines by effective suppression of pro-inflammatory mediators and minimal inhibition of anti-inflammatory cytokine production.

\section{CT20126 promotes skin allograft survival}

We next examined whether CT20126 promotes skin 


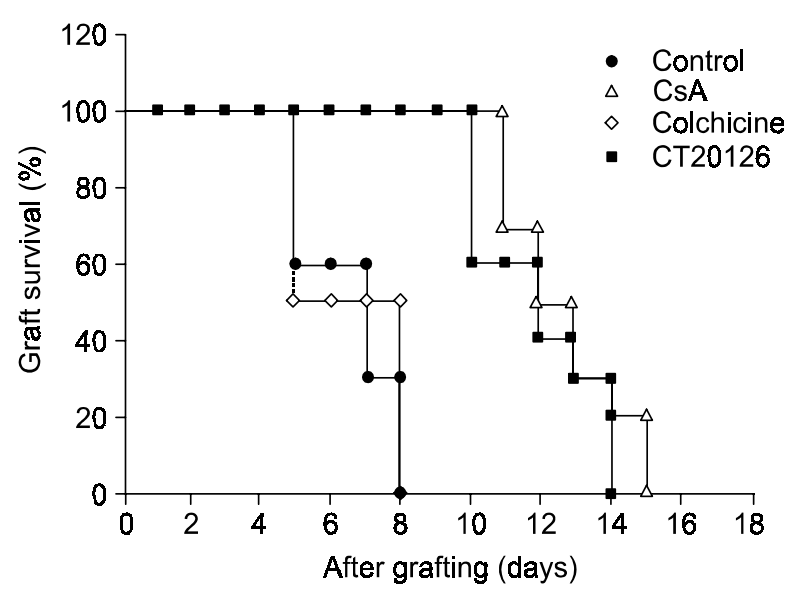

Figure 4. Effects of CT20126 on survival of skin allografts. C57BL/6 $\left(\mathrm{H}-2^{b}\right)$ mice were grafted with full thickness skins from BALB/c $\left(\mathrm{H}-2^{\mathrm{d}}\right)$ mice and the grafted donor skin was covered with a vaseline gauze and tied with a band-aid for mechanical fixation. Mice were i.p. administrated with or without daily doses of $1 \mathrm{mg} / \mathrm{kg}$ of CT20126, $1 \mathrm{mg} / \mathrm{kg}$ of CsA or $1 \mathrm{mg} / \mathrm{kg}$ of colchicine. The grafts were considered to be rejected when at least $70 \%$ of the graft tissue had disappeared or had shrunken. Graft survival on a specific day was expressed as the proportion of non-rejected grafts out of the total grafts.

allograft survival after grafting the skins from BALB/C mice to C57BL/6 mice. Administration of CT20126 prolonged the survival of allograft skins compared with control allograft (Figure 4). The medium survival time of BALB/C allografts in untreated $\mathrm{C} 57 \mathrm{BL} / 6$ was $6.7 \pm 1.2$ days, conversely graft recipients with CT20126 prolonged graft survival to $11.8 \pm 2.1$ days $(P<0.05)$. Treatment with $\mathrm{CsA}$ at the same concentrations enhanced graft survival to $12.3 \pm 0.8$ days $(P<0.01)$, but colchicine did not with a graft survival time to $6.2 \pm 1.8$ days $(P<0.05)$. No deleterious or harmful effects of CT20126 and CsA on the health (liver injury and body weight) of graft recipients were observed as determined by measuring their body weight and plasma levels of lactate dehydrogenase and aspartate aminotransferase. These results indicate that CT20126 significantly promotes skin allograft survival and that this protective effect was comparable to that of CsA.

\section{Discussion}

The need to manage detrimental immunological reactions occurring after transplantation, in the cases of autoimmunity, allergic reactions or in different states of hypersensitivity still evokes the search for new and safe immunosuppressive drugs. We here synthesized 100 derivatives (CT compounds) from colchicine, which has been used as an anti-inflammatory drug (Ostermann et al., 1993), and screened their immunosuppressive and anti-inflammatory effects in in vitro and in vivo. Of them, СT20126 was found to suppress the production of Th1-like proinflammatory cytokines but inhibit in part the production of anti-inflammatory Th2 cytokines, resulting in the prolongation of skin allograft survival. These results indicate that the new compound CT20126 possesses immune suppressive activity and can be used for therapeutic drug for allogeneic transplantation reaction and inflammatory diseases.

Immune cells including lymphocytes and macrophages infiltrate into graft and inflammation sites and produce various inflammation-associated cytokines and mediators such as NO, TNF- $\alpha$, and ILs, which are highly correlated with the pathogenesis of many acute and chronic human inflammatory diseases, including transplantation rejection, asthma, and rheumatoid arthritis (Tan et al., 2002; Schuerwegh et al., 2003). In this study, CT20126 effectively inhibited the accumulation of NO, TNF- $\alpha$, and IL- $1 \beta$ in culture media and the mRNA and protein levels of iNOS, TNF- $\alpha$, and IL- $1 \beta$ in macrophages stimulated with LPS, indicating that this compound blocks inflammatory gene expression at the transcription step. The inhibitory effect of this drug was nearly comparable to that of the well-known immune suppressant CsA. These results suggest that CT20126 can inhibit the expression of inflammatory genes via transcriptional inhibition and prevent the pathogenesis and progression of human inflammatory diseases and transplantation rejection.

The balance of Th1/Th2 cytokines is critically involved in the pathogenesis of inflammatory diseases and transplantation rejection (Holan et al., 2006). The polarization of immune responses towards either Th1 or Th2 direction has been described as a critical determinant for transplantation rejection in animal models. Acute allograft rejection represents a typical Th1 response characterized by a predominant production of pro-inflammatory cytokines, IL-2, TNF- $\alpha$, and IFN- $\gamma$, with a low production of Th2 cytokines, IL-4, IL-10, and TGF- $\beta$ (Wu et al., 1992; Strom et al., 1996). Previous studies have also shown that production of NO represents one of the mechanisms participating in graft rejection (Worrall et al., 1995). Kinetics of allograft rejection and the fate of skin allografts correlated with the level of NO or its metabolites produced in the graft (Krulova et al., 2002) and the inhibition of NO production resulted in prolonged allograft survival (Worrall et al., 1995). Our results showed that CT20126 significantly suppressed the production of NO, TNF- $\alpha$, IL-1 $\beta$, and IL-2 and failed to effectively inhibit IL-4 and IL-10 in the sponge matrix allograft model (Figure 3 ). The immune regulatory effect of CT20126 was comparable or similar to that of CsA, 
indicating that this compound can be used as an immune suppressant. We demonstrated that this compound reduced the rejection of mouse skin allografts by suppressing Th1 cytokine production and NO synthesis. Thus, this compound decreases the ratio of Th1/Th2 cytokines, resulting in significant prolongation of skin allografts.

Th1 cell-dependent cytokines such as IL-2, IFN- $\gamma$ and TNF- $\alpha$ activate macrophages to produce reactive oxygen intermediates and $\mathrm{NO}$, stimulate their phagocytic functions, and enhance their ability of antigen presentation by up-regulating $\mathrm{MHC}$ class II molecules. Consequently, Th1 cells are involved in cell-mediated immunity (Mosmann et al., 1986; Abbas et al., 1996). Th1-mediated immunity is involved in the pathogenesis of several organ-specific inflammatory diseases including rheumatoid arthritis and atherosclerosis (Benagiano et al., 2003; Calcagni and Elenkov, 2006). Th2 cells-dependent cytokines IL-4 and IL-10 provide potent help for B-cell activation and $\mathrm{Ig}$ class switching to $\lg \mathrm{E}$ and subtypes of $\mathrm{lgG}$. Thus, Th2 cells mediate allergic immune responses and have been associated with downmodulation of macrophage activation, which is conferred largely by the anti-inflammatory effects of IL-4 and IL-10 (Mosmann et al., 1986; Abbas et al., 1996). We showed that CT20126 effectively inhibited Th1 cell-dependent cytokine production, with little suppressive effect on Th2 cytokine production in vivo, suggesting that this drug can control the pathogenesis and development of rheumatoid arthritis and atherosclerosis as well as transplantation rejection, but not Th2-mediated allergic diseases.

In summary, we synthesized the new immune suppressant CT20126, which regulates the expression levels of Th1- and Th2-cytokines and NO production, as well as promotes skin allograft survival. These immunosuppressive effects were comparable to the activity of those of CsA. Thus, this compound may have therapeutic potential for transplantation rejection and numerous inflammatory diseases including rheumatoid arthritis.

\section{Acknowledgment}

This work was supported by Vascular System Research Center grant form Korea Science and Engineering Foundation and Chem-Tech Research Incorporation.

\section{References}

Abbas AK, Murphy KM, Sher A. Functional diversity of helper T-lymphocytes. Nature 1996;383:787-93

Benagiano M, Azzurri A, Ciervo A, Amedei A, Tamburini C, Ferrari M, Telford JL, Baldari CT, Romagnani S, Cassone A, D'Elios MM, Del Prete G. T helper type 1 lymphocytes drive inflammation in human atherosclerotic lesions. Proc Natl Acad Sci USA 2003;100:6658-63

Calcagni E, Elenkov I. Stress system activity, innate and T helper cytokines, and susceptibility to immune-related diseases. Ann N Y Acad Sci 2006;1069:62-76

Ford HR, Hoffman RA, Tweardy DJ, Kispert P, Wang S, Simmons RL. Evidence that production of interleukin 6 within the rejecting allograft coincides with cytotoxic $T$ lymphocyte development. Transplantation 1991;51:656-61

Furukawa H, Oshima K, Tung T, Cui G, Laks H, Sen L. Liposome-mediated combinatorial cytokine gene therapy induces localized synergistic immunosuppression and promotes long-term survival of cardiac allografts. J Immunol 2005;174:6983-92

Gahm C, Holmin S, Rudehill S, Mathiesen T. Neuronal degeneration and iNOS expression in experimental brain contusion following treatment with colchicine, dexamethasone, tirilazad mesylate and nimodipine. Acta Neurochir (Wien) 2005;147:1071-84

Hoffman RA, Ascher NL, Jordan ML, Migliori RJ, Simmons RL. Characterization of natural killer activity in sponge matrix allografts. J Immunol 1988;140:1702-10

Holan V, Krulova M, Pindjakova J, Zajicova A. The role of macrophages and nitric oxide in the effector phase of allotransplantation reaction. Ann Transplant 2001;6:44-6

Holan V, Pindjakova J, Krulova M, Neuwirth A, Fric J, Zajicova A. Production of nitric oxide during graft rejection is regulated by the Th1/Th2 balance, the arginase activity, and L-arginine metabolism. Transplantation 2006;81:1708-15

Krulova M, Zajicova A, Fric J, Holan V. Alloantigen-induced, T-cell-dependent production of nitric oxide by macrophages infiltrating skin allografts in mice. Transpl Int 2002;15:108-16

Lee SJ, Bai SK, Lee KS, Namkoong S, Na HJ, Ha KS, Han JA, Yim SV, Chang K, Kwon YG, Lee SK, Kim YM. Astaxanthin inhibits nitric oxide production and inflammatory gene expression by suppressing $I_{\kappa} B$ kinase-dependent NF- $\mathrm{KB}$ activation. Mol Cells 2003;16:97-105

Matsue $\mathrm{H}$, Yang $\mathrm{C}$, Matsue $\mathrm{K}$, Edelbaum D, Mummert M, Takashima A. Contrasting impacts of immunosuppressive agents (rapamycin, FK506, cyclosporin A, and dexamethasone) on bidirectional dendritic cell-T cell interaction during antigen presentation. J Immunol 2002;169:3555-64

Mosmann TR, Cherwinski H, Bond MW, Giedlin MA, Coffman $\mathrm{RL}$. Two types of murine helper T cell clone. I. Definition according to profiles of lymphokine activities and secreted proteins. J Immunol 1986;136:2348-57

Ostermann D, Perico N, Imberti O, Barbui C, Bontempelli M, Remuzzi G. Colchicine allows prolonged survival of highly reactive renal allograft in the rat. J Am Soc Nephrol 1993:4:1294-9

Oswald IP, Gazzinelli RT, Sher A, James SL. IL-10 synergizes with IL-4 and TGF- $\beta$ to inhibit macrophage cytotoxic activity. J Immunol 1992;148:3578-82

Saeed SA, Integlia MJ, Pleskow RG, Calenda KA, Rohrer RJ, Dayal Y, Grand RJ. Tacrolimus-associated eosinophilic 
gastroenterocolitis in pediatric liver transplant recipients: role of potential food allergies in pathogenesis. Pediatr Transplant 2006;10:730-5

Schmidt-Weber CB, Alexander SI, Henault LE, James L, Lichtman AH. IL-4 enhances IL-10 gene expression in murine Th2 cells in the absence of TCR engagement. J Immunol 1999;162:238-44

Schuerwegh AJ, Dombrecht EJ, Stevens WJ, Van Offel JF, Bridts $\mathrm{CH}$, De Clerck LS. Influence of pro-inflammatory (IL-1 $\alpha$, IL-6, TNF- $\alpha$, IFN- $\gamma$ ) and anti-inflammatory (IL-4) cytokines on chondrocyte function. Osteoarthritis Cartilage 2003;11:681-7

Smith JM, Nemeth TL, McDonald RA. Current immunosuppressive agents: efficacy, side effects, and utilization. Pediatr Clin North Am 2003;50:1283-300

Strom TB, Roy-Chaudhury P, Manfro R, Zheng XX, Nickerson
PW, Wood K, Bushell A. The Th1/Th2 paradigm and the allograft response. Curr Opin Immunol 1996;8:688-93

Tan M, Di Carlo A, Liu SQ, Tector AJ, Tchervenkov JI, Metrakos P. Hepatic sinusoidal endothelium upregulates IL- $1 \alpha$, IFN- $\gamma$, and iNOS in response to discordant xenogeneic islets in an in vitro model of xenoislet transplantation. J Surg Res 2002;102: 229-36

Worrall NK, Lazenby WD, Misko TP, Lin TS, Rodi CP, Manning PT, Tilton RG, Williamson JR, Ferguson TB. Modulation of in vivo alloreactivity by inhibition of inducible nitric oxide synthase. J Exp Med 1995;181:63-70

Wu CJ, Lovett M, Wong-Lee J, Moeller F, Kitamura M, Goralski TJ, Billingham ME, Starnes VA, Clayberger C. Cytokine gene expression in rejecting cardiac allografts. Transplantation 1992;54:326-32 